Petrology, Sedimentology, and Diagenesis of Hemipelagic Limestone and Tuffaceous Turbidites in the Aksitero Formation, Central Luzon, Philippines

GEOLOGICAL SURVEY PROFESSIONAL PAPER 1112

Prepared in cooperation with the Bureau of Mines,

Republic of the Philippines, and the

U.S. National Science Foundation
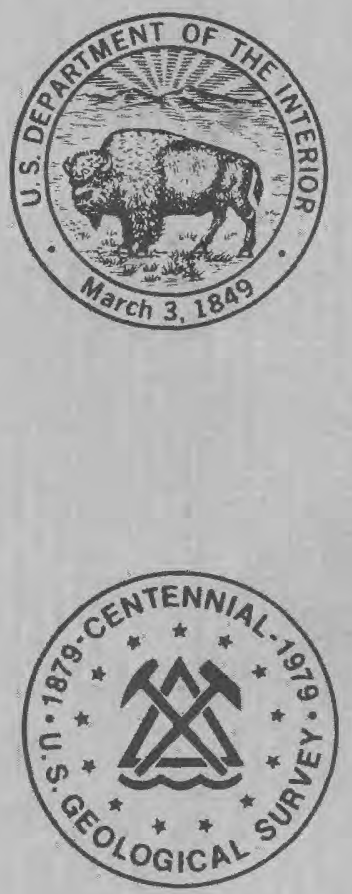


\section{Petrology, Sedimentology, and Diagenesis of}

Hemipelagic Limestone and Tuffaceous Turbidites in the Aksitero Formation, Central Luzon, Philippines

By ROBERT E. GARRISON, ERNESTO ESPIRITU, LAWRENCE J. HORAN, and LAWRENCE E. MACK

GE O L O G I C A L S U R V E Y PROFES S I N A L P A P E R 11112

Prepared in cooperation with the Bureau of Mines, Republic of the Philippines, and the U.S. National Science Foundation

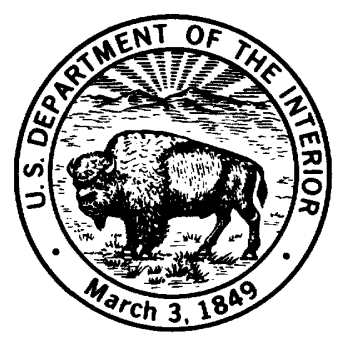




\section{UNITED STATES DEPARTMENT OF THE INTERIOR}

GECIL D. ANDRUS, Secretary

GEOLOGICAL SURVEY

H. William Menard, Director

United States. Geological Survey.

Petrology, sedimentology, and diagenesis of hemipelagic limestone and tuffaceous turbidites in the Aksitero Formation, central Luzon, Philippines.

(Geological Survey Professional Paper; 1112)

Bibliography: p. 15-16

Supt. of Docs. No.: I 19.16:1112

1. Limestone-Philippine Islands-Luzon. 2. Turbidites--Philippine Islands-Luzon. 3. Geology, Stratigraphic--Eocene. 4. Geology, Stratigraphic--Oligocene. 5. Geology--Philippine Islands-Luzon. I. Garrison, Robert E. II. United States. Bureau of Mines. III. Philippines (Republic) IV. United States, National Science Foundation. V. Title. VI. Series: United States. Geological Survey. Professional Paper; 1112. QE471.15.L5U54 $1979 \quad 552 ' .5 \quad 79-607993$

For sale by the Superintendent of Documents, U.S. Government Printing Office Washington, D.C. 20402

Stock Number 024-001-03220-1 


\section{CONTENTS}

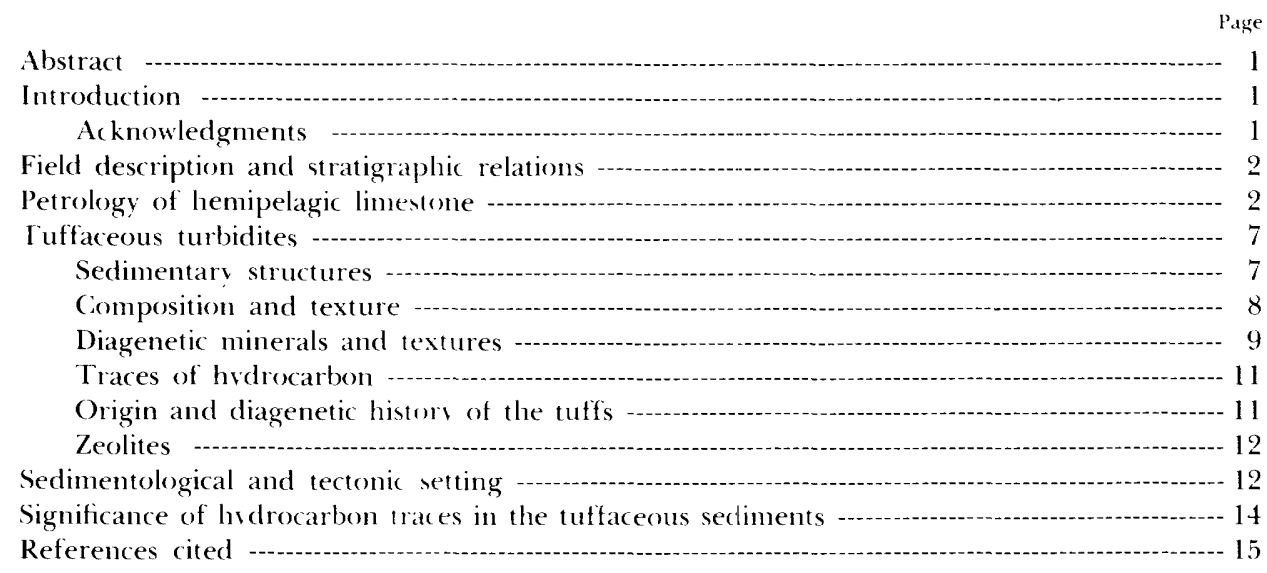

\section{ILLUSTRATIONS}

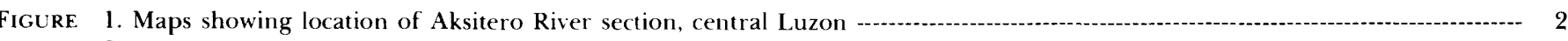

2. Composite Cenozoic stratigraphic section for central Luzon -

3. Photograph showing outcrop of thin-bedded hemipelagic limestone and tuff, Aksitero Formation --.-..--.-. 4

4. Photomicrographs of hemipelagic limestone -

5. Transmission electron micrographs of micritic matrix in hemipelagic limestone - 5

6. Transmission electron micrographs of nannofossils and products of diagenesis in hemipelagic limestone --.......--......- 6

7. Photograph showing slabbed and polished surface of tuffaceous turbidite bed -

8. Photomicrographs of turbidite tuff lavers - 8

9. Photomicrograph of turbidite tuff layer showing volcaniclastic grains embedded in matrix of small glass shards replaced by mordenite

10. Scanning electron micrographs of zeolites in tuffaceous turbidite

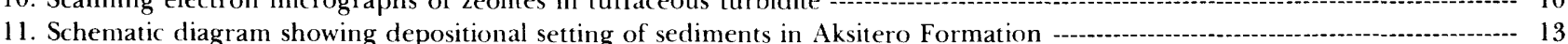

12. Sketch showing early Tertiary plate tectonic reconstruction of the northern Philippines and Marianas region ------.-------.-- 14 



\title{
PETROLOGY, SEDIMENTOLOGY, AND DIAGENESIS OF HEMIPELAGIC LIMESTONE AND TUFFACEOUS TURBIDITES IN THE AKSITERO FORMATION, CENTRAL LUZON, PHILIPPINES
}

\author{
By Rober' E. Garrison, Ernesto Espiritu, ${ }^{1}$ \\ LAWrence J. Horan, AND LAWRENCE E. MaCk
}

\begin{abstract}
The Aksitero Formation of central Luzon is an upper Eocene and lower Oligocene sequence of evenly bedded hemipelagic limestone with a few thin interlayers of tuffaceous turbidites. The limestone consists chiefly of planktonic foraninifers and calcareous nannofossils, with up to 30 percent of noncarbonate components, chiefly volcaniclastic debris. The tuff layers are graded beds composed mainly of glass shards, pumice fragments, crystals, and fine-grained volcanic rock fragments. Hydrocarbons migrated into the pores of the tuffaceous layers early during diagenesis but they were subsequently flushed out and only bitumen remains, chiefly as thin coatings on grains and within pumice vesicles. Later during diagenesis, zeolites (mordenite and clinoptilolite) and secondary calcite preferentially replaced glass shards and pumice fragments. Deposition of the Aksitero Formation probably occurred at depths of at least 1,000 meters within a subsiding basin adjacent to an active island arc system. Submarine ash eruptions of silicic composition caused volcaniclastic turbidity currents that occasionally reached the basin floor. The more proximal facies of these volcaniclastic deposits may be prospective for hydrocarbons.
\end{abstract}

\section{INTRODUCTION}

This study is a product of a cooperative research program on the origin and distribution of energy resources along tectonically active plate margins in east Asia. One phase of this research has been concerned with the sedimentology of basinal sedimentary sequences that are potential source rocks for hydrocarbons. Among rocks of this kind we have concentrated mainly on petroliferous diatomaceous deposits of late Tertiary age in many parts of the north circum-Pacific area (Garrison, 1975). The limestone and tuffaceous turbidites of the early Tertiary Aksitero Formation described here are a somewhat different kind of basinal sequence which appears, however, to have similar potential for the generation of hydrocarbons. ${ }^{n \cdots}$

Tertiary sedimentary rocks exposed along the Aksitero River in the foothills of the Zambales Mountains west of the Central Valley of Luzon (fig. 1) form one

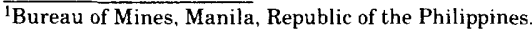

of the standard biostratigraphic reference sections for Cenozoic rocks in the Philippines. Among other workers, Corby and others (1951; p. 105-108), Bandy (1962, p. 18-23; 1963, p. 1738-1739), Amato (1965, p. 13-23), Divino-Santiago (1963, p. 73), Grey (1967, p. 20), Roque, Reyes, and Gonzales (1972, p. 17-19), and Ingle $(1975$, p. 840-848) have referred to this section. The sedimentary rocks in this sequence consist of tuffaceous mudstone and sandstone of the Moriones Formation underlain by fine-grained foraminiferal limestone with thin calcareous tuff interlayers (fig. 2). These basal calcareous rocks were formerly considered part of the Moriones Formation and informally known as the Bigbiga limestone (Bandy, 1962 ; p. 18). Amato $(1965$, p. 13,14$)$ proposed the name Aksitero Formation for the limestone unit and some bverlying clastic rocks. On the basis of rare benthonic foraminifers, he suggested that the limestone was deposited in a deep bathyal environment, at water depths in excess of $1,000 \mathrm{~m}$ (see also Bandy, 1963, p. 1738; Ingle $\$ 975$, p. 840). Our study of the petrology and sedpmentary structures in these rocks generally confirms; Amato's assessment and provides addirionar details on the sedimentological and diagenetic history of these rocks. In addition, we propose a depositional model that has implications for the prediction of lateral facies relations and possibly also for the occurrence of hydrocarbons.

\section{ACKNOWLEDGMENTS}

David Bukry identified nannofossil forms in electron micrographs of the limestone. We are grateful to James Boles, Ray Christopher, R. V. Fisher,' R. S. Fiske, Azuma Iijima, J. C. Maher, M. J. Termän, and A. C. Waters for discussions and suggestions. This report was prepared in cooperation with the ${ }^{\mathrm{f}}$ Philippine Bureau of Mines, and we wish to, acknowledge the help of Director Juanito C. Fernandez, Mr. Felipe U.. Francisco, and Mr. Oscar Crispin. The work was funded in 

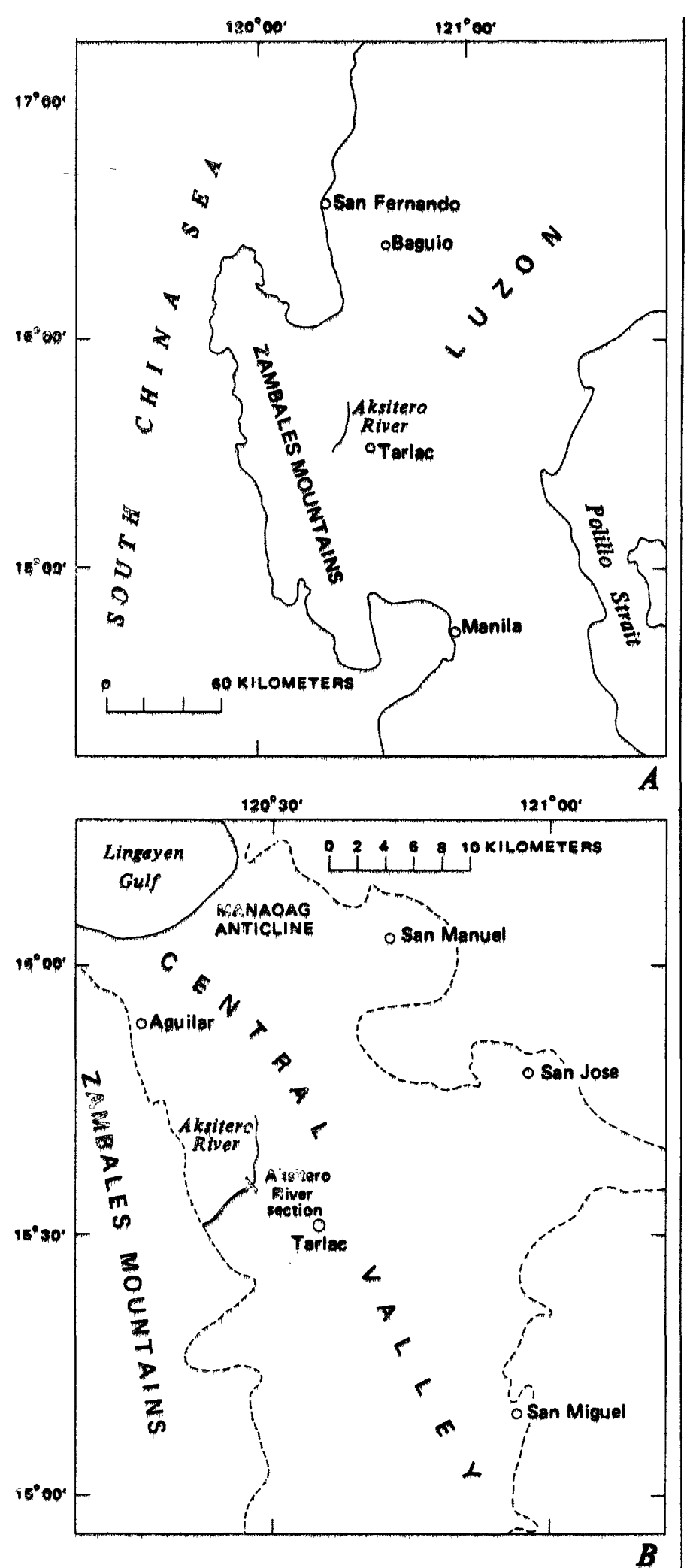

Figure 1.-Location of Aksitero River section, central Luzon, Philippines. A, Index map of central Luzon showing location of Aksitero River, $B$, Enlarged view of area near Zambales Mountains showing location of section. Dashed line indicates approximate boundary of Central Valley. part by the National Science Foundation and carried out in conjunction with the Circum-Pacific Council Map Project.

\section{FIELD DESCRIPTION AND STRATIGRAPHIC RELATIONS}

The Aksitero Formation at its type area along the upper Aksitero River is about $200 \mathrm{~m}$ thick (fig. 2). On the basis of planktonic foraminifers, Amato (1965, p. 13-14) assigned it a late Eocene and early Oligocene age. According to Roque, Reyes, and Gonzales (1972, p. 18, 19), the lower $148 \mathrm{~m}$ of the formation at the type area is mainly limestone of Eocene age, and the upper $52 \mathrm{~m}$ is interbedded limestone and tuffaceous sandstone of Oligocene age. The unit lies unconformably above highly weathered, poorly exposed, and apparently complexly deformed mafic to intermediate igneous rocks of the Mesozoic to early Tertiary(?) basement complex of the Zambales Mountains (Corby and others, 1951, p. 105; Philippines Bureau of Mines, 1976, p $63-65$ ). This complex may be in part an ophiolitic sequence (Ingle, 1975, p. 848). Overlying the Aksitero Formation is the Moriones Formation of early and middle Miocene age composed of tuffaceous mudstone, sandstone, and conglomerate; the contact between the two units is poorly exposed, but apparently it is unconformable and locally may be faulted.

The Aksitero Formation is composed principally of thin-bedded pale-yellow to yellowish-white fine-grained limestone that ranges from argillaceous and slightly fissile to nearly pure, very hard, and conchoidally fractured (fig. 3). A few limestone beds are light greenish gray or pink. Interlayered with the limestone are a few beds of zeolitized tuffaceous turbidites, most less than $10 \mathrm{~cm}$ thick.

\section{PETROLOGY OF HEMIPELAGIC LIMESTONE}

The predominant rock in the Aksitero Formation is fine-grained foraminiferal biomicrite with tests of planktonic foraminifers dispersed in a nannofossil-rich micritic matrix (fig, 4). Pelagic microorganisms are thus the most common constituent, but the limestone also contains up to 30 percent noncarbonate detrital components and is thus best categorized as a hemipelagic deposit. Both thick- and thin-shelled planktonic foraminifers are present; compactional crushing commonly has fractured the walls of the thin-shelled forms (figs. 4C and 4D). This kind of deformation probably also produced the abundant small broken fragments of foraminiferal shell walls dispersed in the matrix.

Comparatively rare benthonic foraminifers make up less than 5 percent of the foraminiferal population, and 


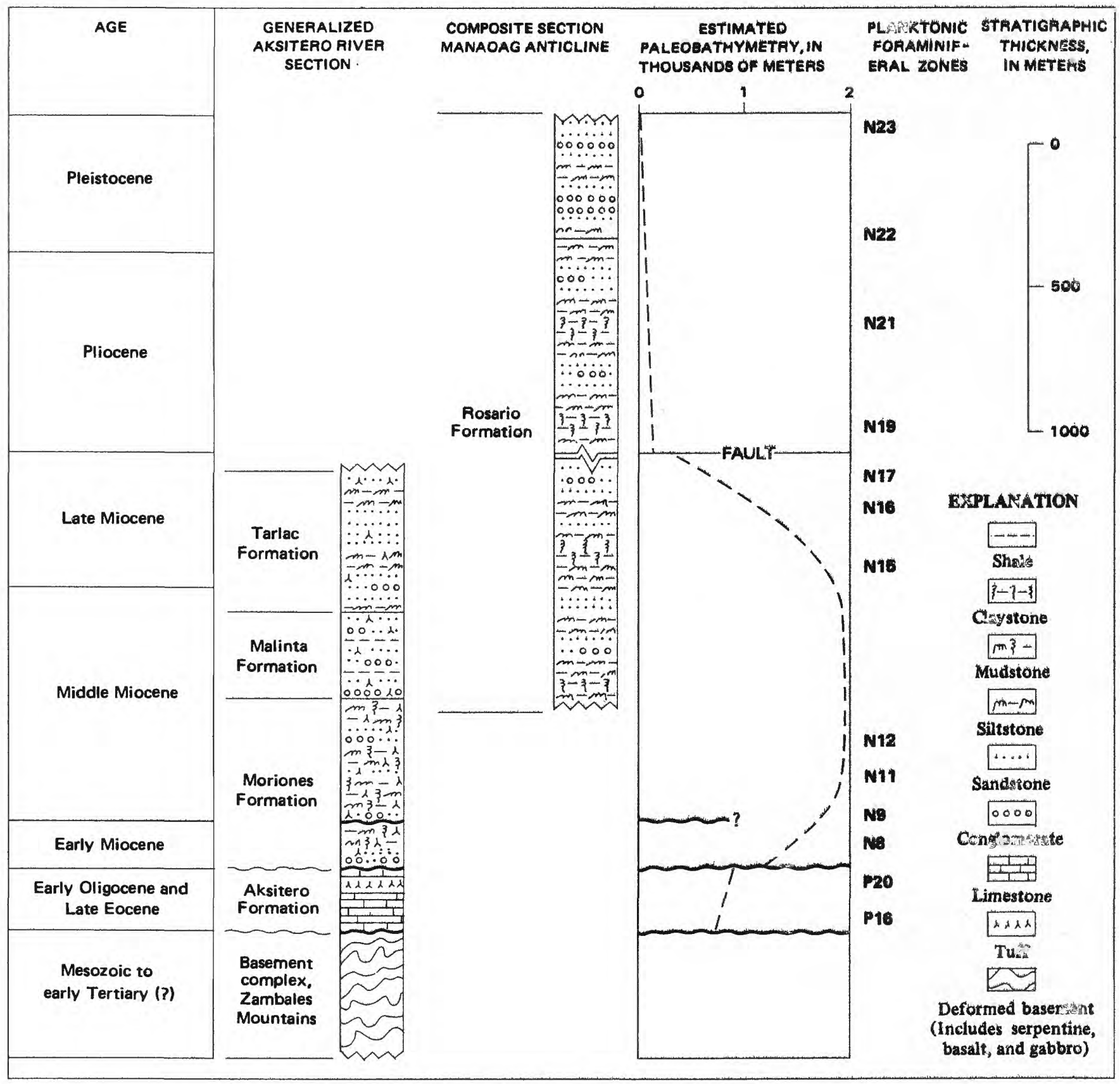

FrgurE 2.-Composite Cenozoic stratigraphic section for central Luzon, with paleobathymetric curve based on microfacna. Modified from Ingle (1975, p. 840).

in one specimen we noted very rare echinoderm fragments. Other microfossils present in generally small numbers are radiolarians, sponge spicules, and phosphatic fish remains. Very fine grained cristobalite has replaced most shells of the siliceous microfossils, and secondary calcite fills some radiolarian molds.

Nannofossils include spherical shells of Thoracosphaera, coccoliths, and discoasters (figs. 5, 6A, 6C). Among the discoasters is one species, Discoaster barbadiensis Tan Sin Hok (figs. $5 A$ and $6 A$ ), whose range of middle to upper Eocene (Bukry, 1973, p. E5s) confirms Amato's (1965, p. 13, 14) age dating of the lows part of the Aksitero Formation. Also present are coccoliths of the genera Coccolithus and Peticulo"mristra (David Bukry, written commun., 157\%).

The chambers of the planktonic foraminifers contain a variety of different materials. Nannofossil-rich micrite partly or entirely fills some chambers. Others contain minerals that either precipitated in void space or replaced mierite; these minerals include secondary 


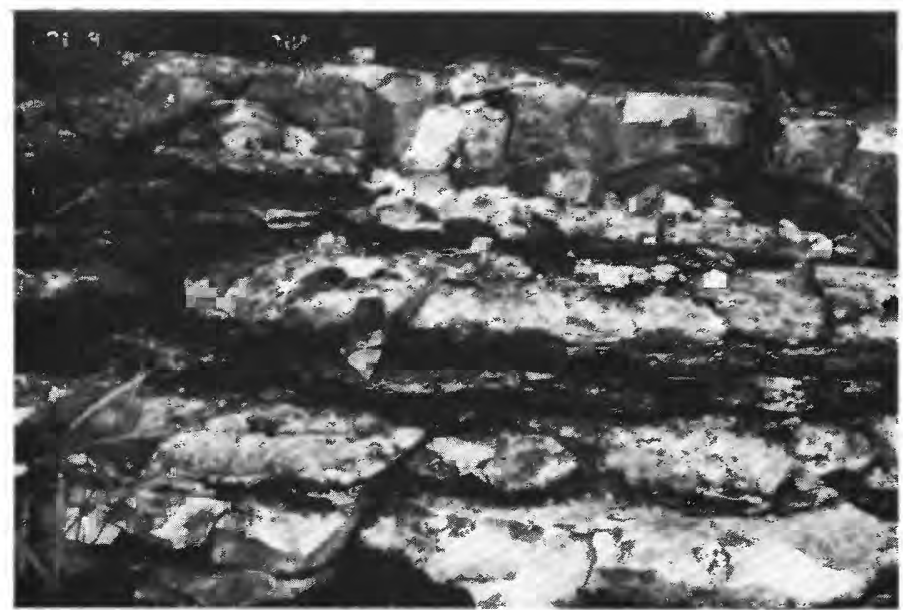

FigURE 3,-Outcrop of thin-bedded hemipelagic limestone and tuff in Aksitero Formation, Aksitero River section.

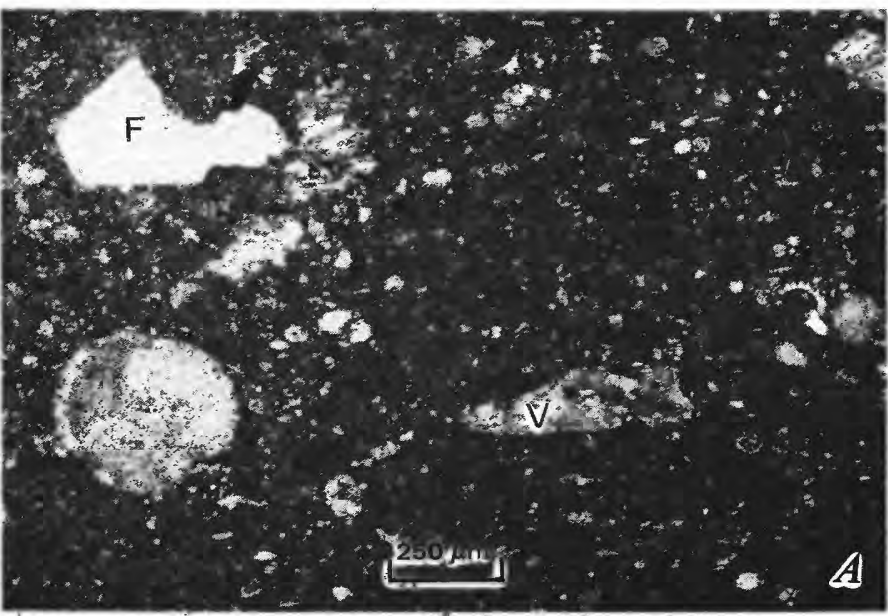

se

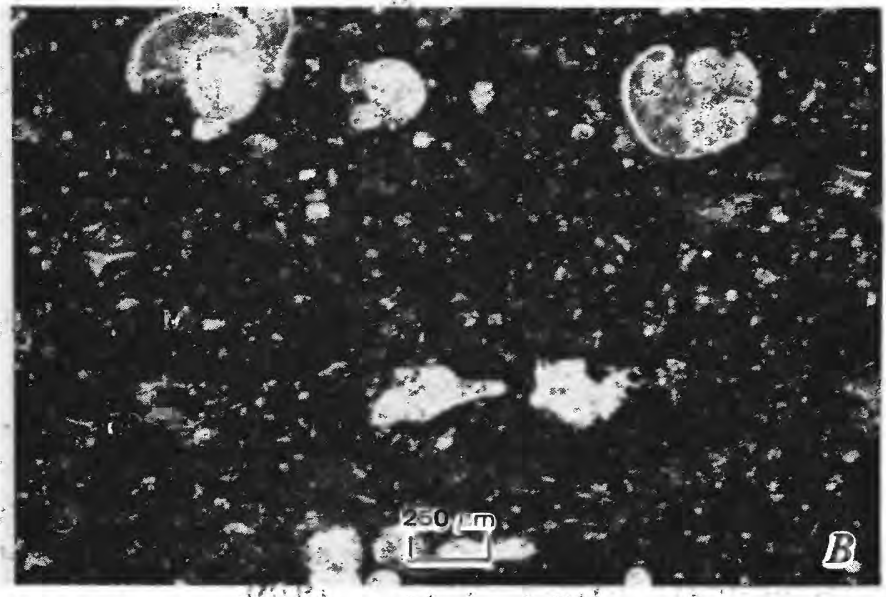

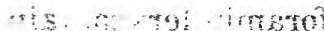

FIGURF 4.-Photomicrographs of hemipelagic limestone in Aksitero Formątion. Plane-polarized light. A, Planktonic foraminiferal tests and volcanic detritứs in narnofossil-rich micritic matrix. Embayed

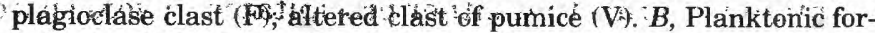

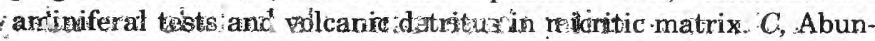

calcite (fig. 6C), zeolites (probably clinoptilolite), authigenic smectites, optically length-fast chalcedony, and a light-brownish very fine grained mineral with very low birefringence that X-ray diffraction suggests is cristobalite. Very commonly, cristobalite partly replaces the micritic fillings of shell chambers. Apparently the interiors of foraminiferal chambers provide a chemical milieu that is conducive to the growth of a variety of secondary minerals.

Inorganic detrital components in the limestone appear to be largely of volcanic origin and are present in various amounts. Measurements of insoluble residues in nine samples indicated a range of 13 to 30 percent, with an average of 21 percent. Some of this noncarbonate material consists of clay minerals dispersed in the micritic matrix (fig. $5 C$ ). Scattered sand- to coarsesilt-size grains include the following:
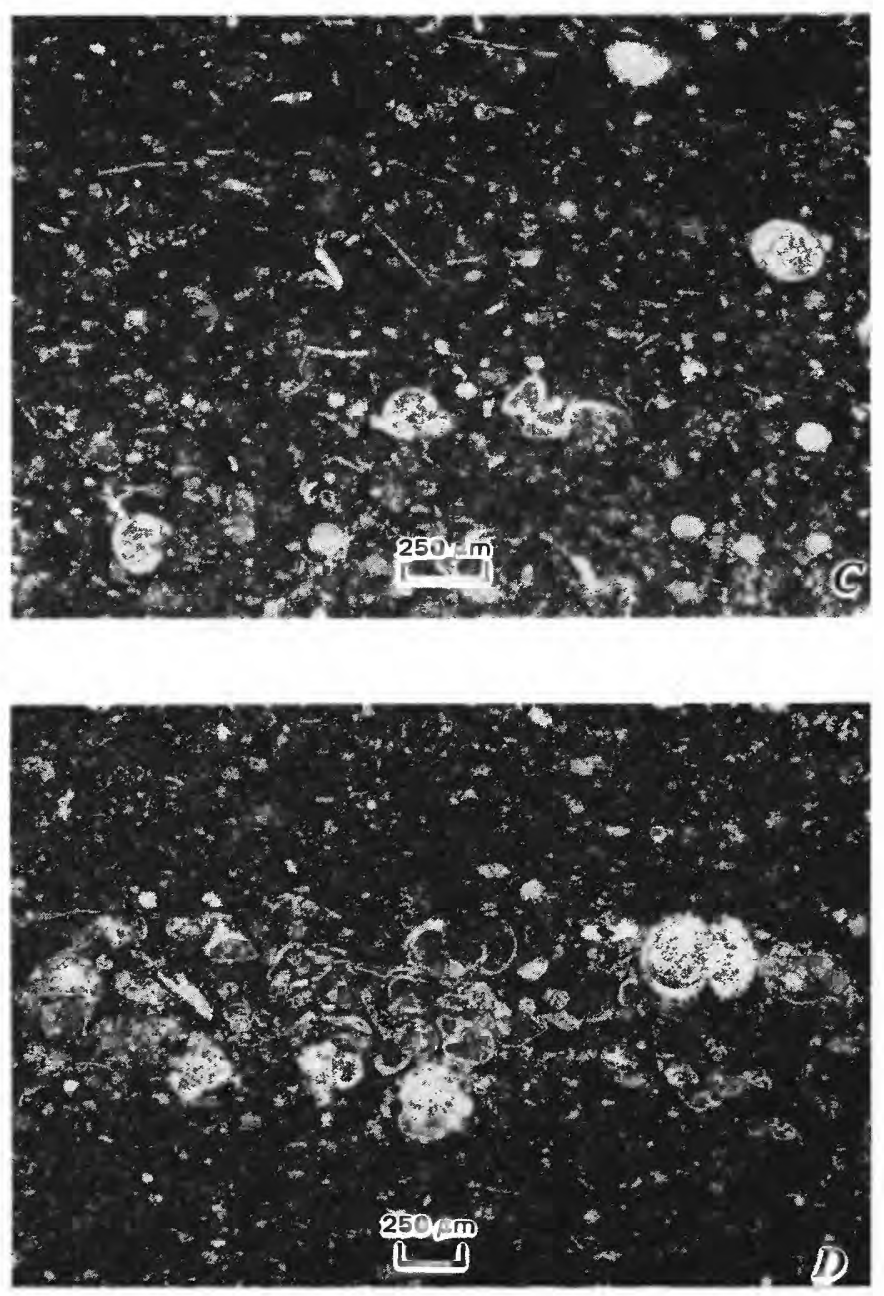

dant spicules and compactionally flattened foraminiferal tests. $D$, Lamina rich in foraminiferal tests, probably the product of winnowing of micrite by weak bottom current. Many thin-shelled tests are broken, whereas thicker shelled ones tend to be intact. 

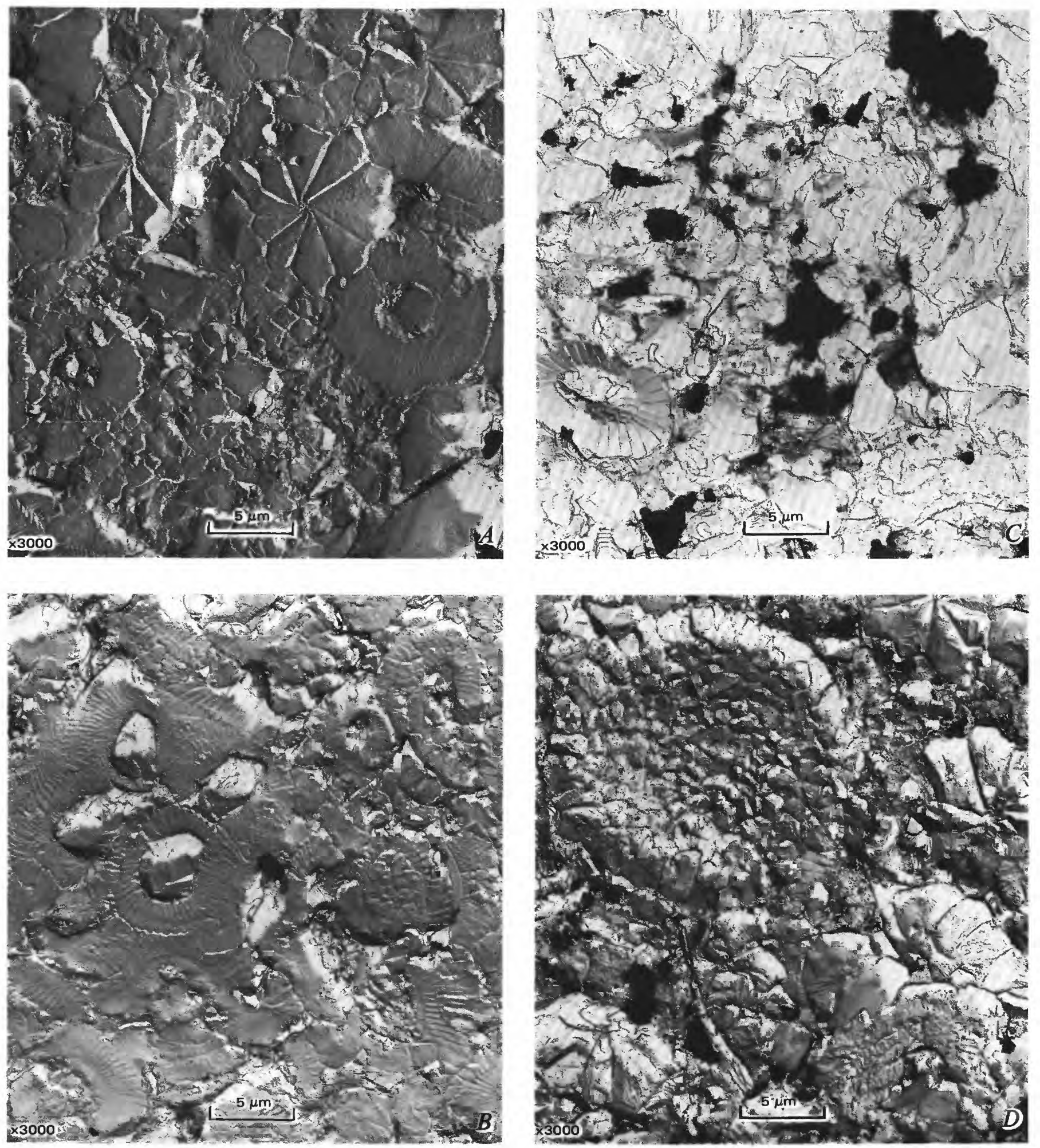

FIGURE 5.-Transmission electron micrographs of micritic matrix in hemipelagic limestone, Aksitero Formation. Samples prepared by two-stage replica method (Fischer and others, 1967). A, Micrite containing coccoliths and discoasters, including Discoaster barbadiensis Tan Sin Hok, at top. B, Micrite composed largely of coccoliths and fragments of coccoliths. Several coccoliths have overgrowths of

secondary calcite crystals (center left). $C$, Micrite containing coccoliths, authigenic calcite, and clay minerals (dark particles). Wellpreserved coccolith (lower left) is Coccolithus pelagicus (Wallich) Schiller. D, Nearly tangential section through shell of Thoracosphaera. Surrounding micrite consists of discoasters, coccolith fragments, authigenic calcite, and clay minerals. 

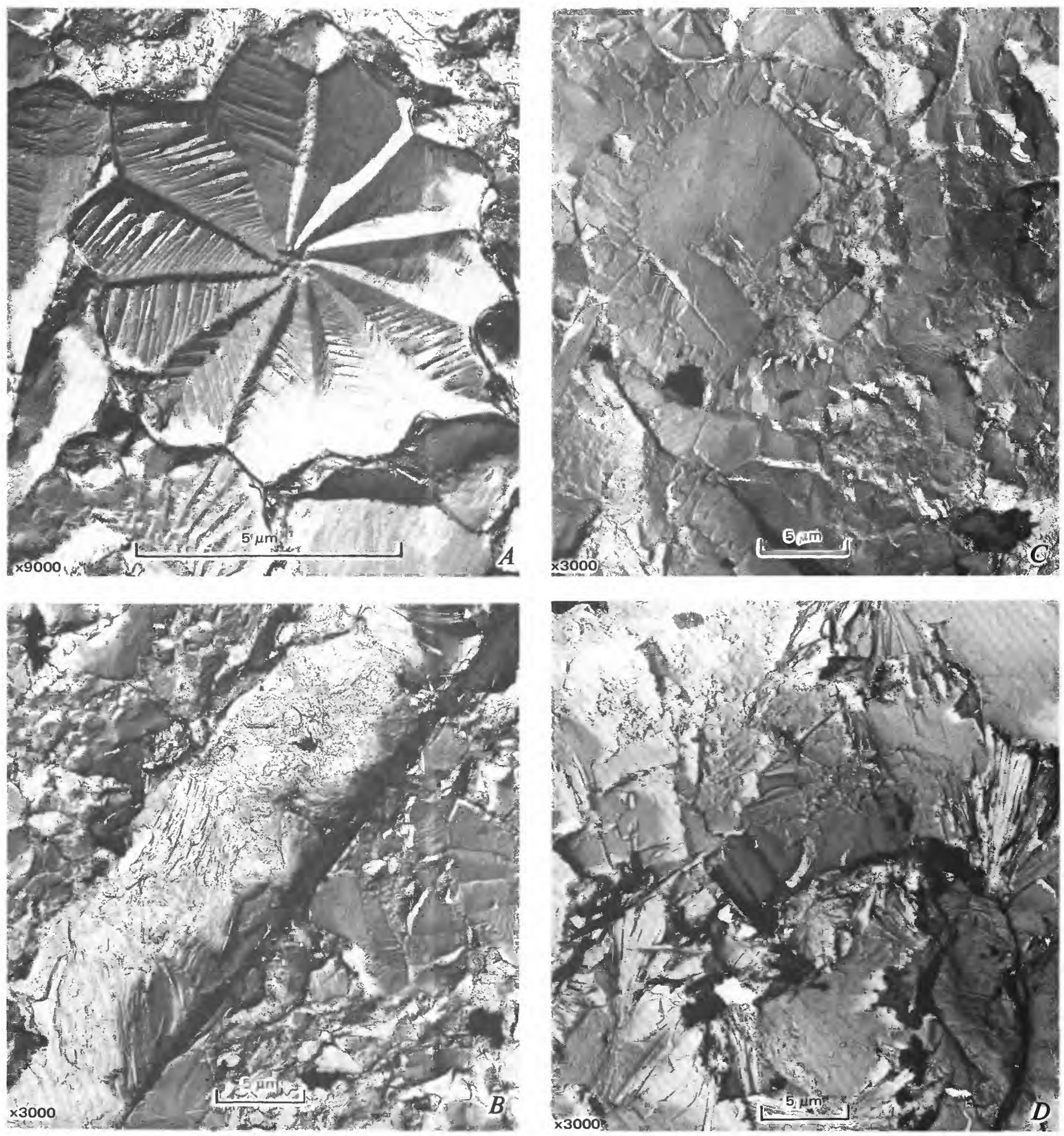

FIGURE 6.-Transmission electron micrographs of nannofossils and products of diagenesis in hemipelagic limestone, Aksitero Formation. Samples prepared by two-stage replica method (Fischer and others, 1967). A, Discoaster barbadiensis Tan Sin Hok. This species ranges from middle to late Eocene. $B$, Lithoclast of tuffaceous mudstone, largely recrystallized to secondary smectite that shows welldeveloped 001 cleavage faces. $C$, Micritic matrix has undergone re-

crystallization causing partial replacement of many nannofossils. Circular Thoracosphaera shell contains relatively coarse, subhedral to euhedral crystals of secondary calcite that have replaced part of coccolith filling. $D$, Volcanic glass shard. Acicular crystals of mordenite and subhedral to euhedral crystals of secondary calcite have replaced glass. 
1. Euhedral to broken or embayed angular crystals of plagioclase (fig. $4 A$ ).

2. Elongated fragments of altered pumice with long tube vesicles (figs. 4A, 4B). Most appear to be replaced by fine-grained zeolites or coarse secondary calcite.

3. Altered volcanic glass shards, many showing round-bubble vesicles. Diverse minerals replace the shards; these include zeolites (fig. $6 D$ ), cristobalite, smectites, chlorite, and large crystals of calcite.

4. Lithoclasts of brown mudstone composed of well-crystallized secondary smectites that have a distinctive "herringbone" pattern with two preferred crystal orientations (fig. $6 B$ ). Most of these appear to be altered tuffaceous mudstone, because in some the outlines of glass shards are still visible along with radiolarian skeletons. Chlorite is the major component of these lithoclasts in the light-greenish-gray limestone.

5. Lithoclasts composed of brown to yellow volcanic glass fragments replaced by smectites; some lithoclasts contain small plagioclase laths.

In addition to the diagenetic effects noted above, electron microscopy shows that the micritic fraction has undergone some recrystallization. Neomorphic microspar has completely replaced some nannofossils (figs. 5, 6C).

The limestone is unlaminated and has indistinct mottling probably caused by burrowing. Burrows are not conspicuous, however, because the sediment was very homogeneous, without the contrasts in color and texture that normally accentuate burrow fillings. In thin section, the common absence of strongly preferred alinement of linear fabric elements (such as spicules) parallel to bedding also suggests disruption due to burrowing. Some discontinuous laminae in the limestone contain concentrations of foraminiferal tests and sandsize detrital grains. The laminae suggest sporadic winnowing of the sediment by bottom currents (fig. $4 D$ ).

\section{TUFFACEOUS TURBIDITES}

Thin graded beds of tuff, which we interpret as turbidites, are interbedded within the sequence of pelagic limestone. These beds range in thickness from 3 to 15 $\mathrm{cm}$, and in aggregate they form 5-10 percent of the total thickness of the Aksitero Formation.

\section{SEDIMENTARY STRUCTURES}

Most individual tuff beds consist of a basal dark, sand-size part that grades into an upper part of very fine grained, hard, zeolitized, yellowish-white rock. The upper part has a pronounced conchoidal fracture and resembles porcelanite. A few tuff layers consist entirely of fine-grained porcelaneous material; they closely resemble the interbedded pelagic limestone in outcrop. The fine-grained tuffs commonly contain sparse, very faint burrows filled with pelagic limestone. A few beds show complete Bouma sequences, with a to e layers (Bouma, 1962, p. 49-51) in which fine-grained porcelaneous tuff forms the $d$ interval.

One sample shows a composite of two turbidite layers that form a single bed (fig. 7). The lower layer contains Bouma $a, b$, and $c$ intervals. The $c$ interval shows small faint ripple marks and is erosionally truncated by the overlying turbidite layer (see Yamada, 1973, p. 589). The upper turbidite layer contains less sand-size

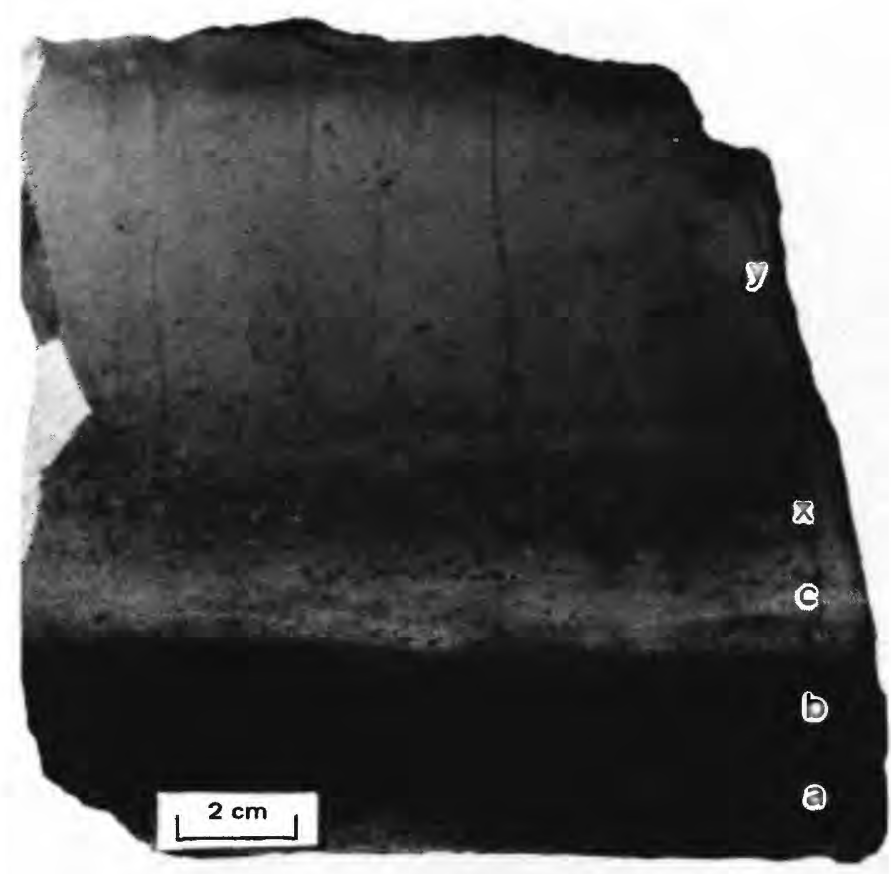

FIGURE 7.-Slabbed and polished surface of tuffaceous turbidite bed, Aksitero Formation, containing two turbidite layers. Letters a, b, and $c$ indicate Bouma intervals. Interval $a$ is massive and $b$ is laminated; both intervals contain numerous pumice fragments (fig. $8 \mathrm{C}$ ). Dark color results from staining by bitumen. The $c$ interval contains faint small-scale ripple marks and cross-laminations. The upper turbidite layer lies just above the $\mathrm{c}$ interval. Poorly sorted basal part (x) contains coarse-sand-size crystals and lithic clasts, and changes upward rather abruptly into very fine grained zeolitized tuff $(y)$ that is very hard and porcelaneous. Top of porcelaneous interval has faint burrows, most noticeable at upper right. Upper turbidite layer is generally finer grained than lower. 
and more fine-grained volcanic material. The gradation to the upper porcelaneous part of the tuff is relatively abrupt, perhaps due to a sedimentological break between the upper low-density and lower highdensity parts of the turbidity flow (Middleton, 1967, p. 487-490; Yamada, 1973, p. 593).

\section{COMPOSITION AND TEXTURE}

Four main components make up the basal sandy parts of the turbidites: crystals, altered glass shards, altered pumice fragments, and lithoclasts of devitrified volcanic glass (fig. 8). The crystals are largely plagioclase; they range from euhedral to rounded to angular and broken; some are strongly embayed. Many show
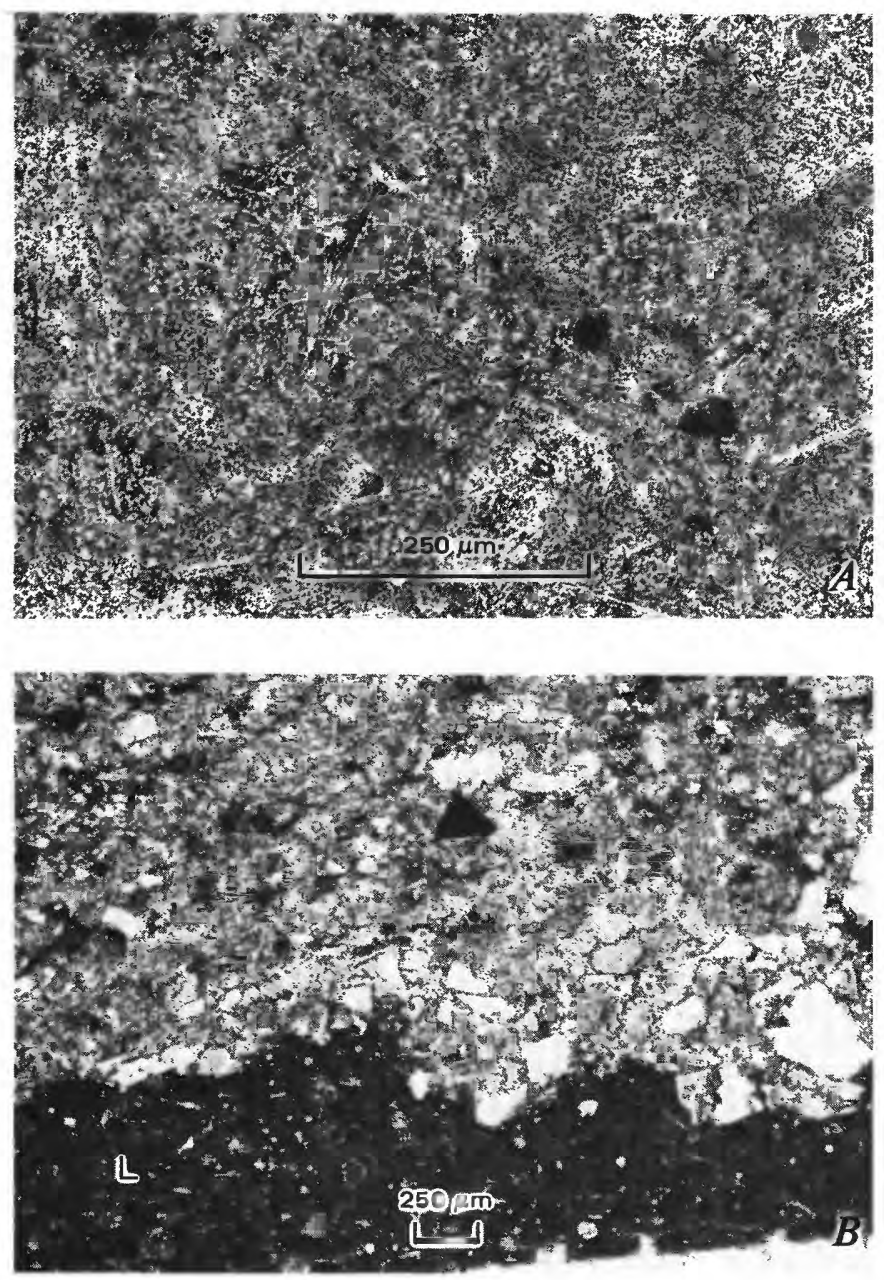

Figure 8.-Photomicrographs of turbidite tuff layers, Aksitero Formation. Plane-polarized light. A, Fine-grained zeolitized tuff from porcelaneous upper part of turbidite layer (fig. 7, y). Outlines of small glass shards are faintly visible. Mordenite has replaced shards. $B$, Basal part of tuffaceous turbidite above hemipelagic limestone (L). Contact is irregular and erosional; angular crystals and lithic fragments in turbidite are poorly sorted. $C$, Large grain in upper center is highly altered pumice fragment replaced by coarse pronounced oscillatory zoning. The glass shards typically show vestiges of round-bubble vesicles. At least two types of pumice fragments are present. The most abundant type contains rather sparse round-bubble vesicles. The other contains long-tube vesicles (see Fiske, 1969). Secondary zeolites and calcite have replaced both the shards and pumice fragments, as discussed below.

Fine- to medium-sand-size lithoclasts of fine-grained volcanic rock are very abundant in the basal parts of the tuffs. Felted masses of feldspar microlites compose some of the lithoclasts, but the most abundant fragments have an intersertal texture of feldspar microlites in a devitrified glass matrix. Some lithoclasts are flow banded, and others have remnants of spherulitic
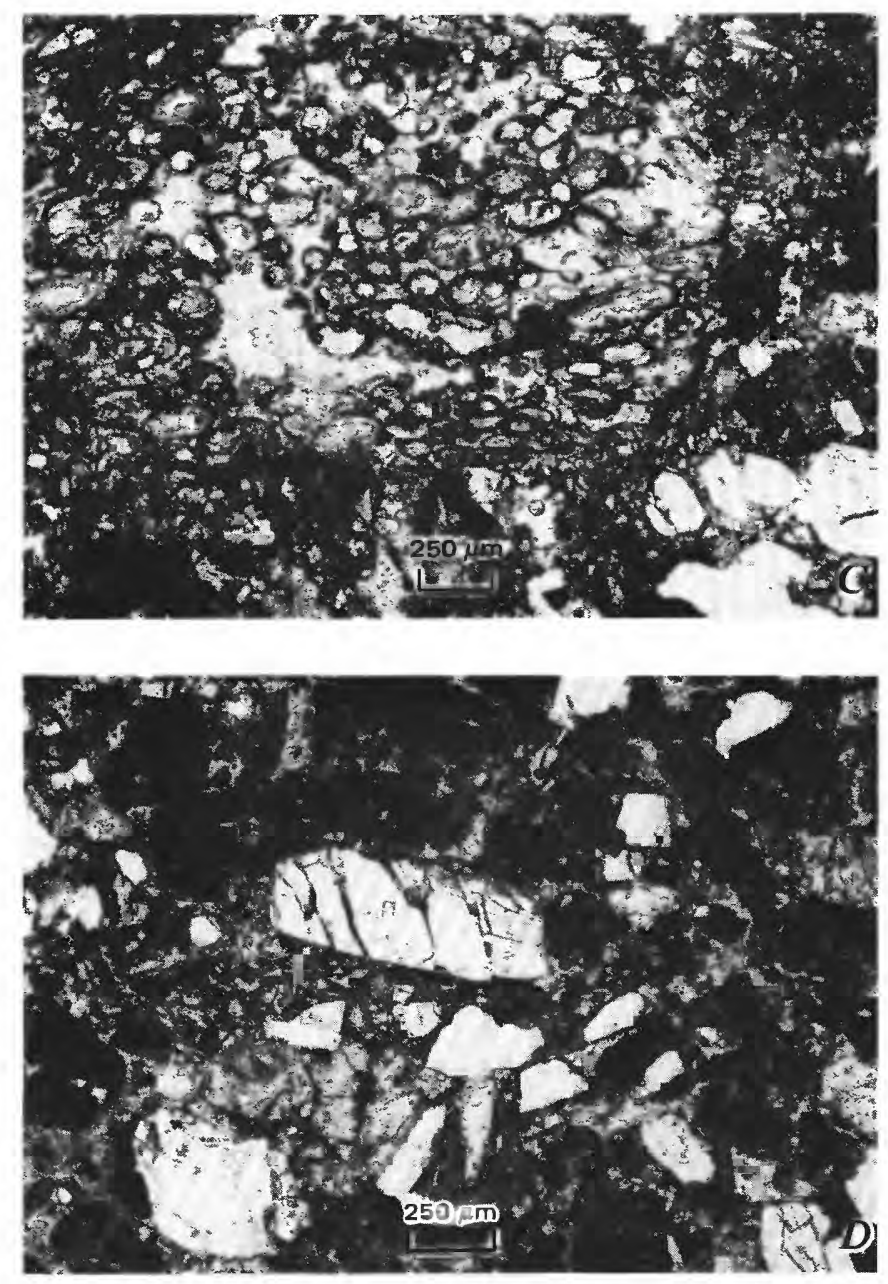

calcite and clinoptilolite. Clinoptilolite also fills many vesicles. Black material is mostly bitumen, which lines most of the vesicles. Specimen from interval a of turbidite bed shown in figure 7. D, Angular crystals and lithic fragments from same specimen as $8 C$. Dark grains are bitumen-impregnated mudstone lithoclasts. Fractures in feldspar crystal (center) also contain bitumen. Irregular mosaic of fine-grained calcite crystals cements grains. 
structures with contraction cracks. Although they are too small and fine grained to be identified with certainty, most of the lithoclasts appear to have been derived from extrusive or shallow intrusive rocks of dacitic or trachyandesitic composition.

In addition to the volcanic components, most of the tuffs also contain small amounts of pelagic sediment; the pelagic sediment suggests erosion, entrainment, and redeposition of this sediment during emplacement of the turbidites. Redeposited pelagic components are present either as micrite and sparse planktonic foraminifers or more rarely as irregularly shaped lithoclasts of pelagic limestone. Other minor components include radiolarian tests, poorly preserved bryozoans, quartz, pyroxene, and amphibole.

Nearly all the sand-size grains in these rocks are very angular (figs. 8 and 9). The sandy parts of the tuffs range from poorly sorted to rather well sorted. The poorly sorted parts have abundant fine-grained matrix that commonly is a mixture of small shards and micrite. The well-sorted parts, which are most common near the base of the turbidite beds, contained appreciable porosity before pore-filling cementation by calcite and zeolites.

The fine-grained porcelaneous upper parts consist chiefly of small glass shards that are replaced by the zeolite mineral mordenite (fig. $8 A$ ). Some small shards are parts of the curved walls of vesicles, but most are elongated fragments that range from about 30 to 100 micrometers long and are 5-10 micrometers thick.

Sorting according to density of the grains produced reverse size grading within the a intervals of some turbidite beds. The lowest parts of these beds contain mainly plagioclase crystals, shards, and felted volcanic lithoclasts; these are overlain by abundant large fragments of pumice whose average grain size greatly exceeds that below (see Fiske and Matsuda, 1964, p. 8788; Fiske, 1969, p. 4; Yamada, 1973, p. 590-591; Niem, 1977 , p. 49-61). These pumiceous layers were very porous and, as described in a following section, became saturated with hydrocarbons and now stand out as dark layers (fig. 7).

\section{DIAGENETIC MINERALS AND TEXTURES}

Diagenesis has profoundly altered the composition and texture of the tuff layers. The most conspicuous diagenetic effects are those produced by growth of zeolites as replacements and as cements. Clinoptilolite and mordenite (figs. $8 A$, and 10 ) were identified by Xray diffraction; the clinoptilolite identification was confirmed by Alietti's (1972) heating test. Mordenite (figs. $8 A, 10 C$, and $10 B$ ) completely replaces the small

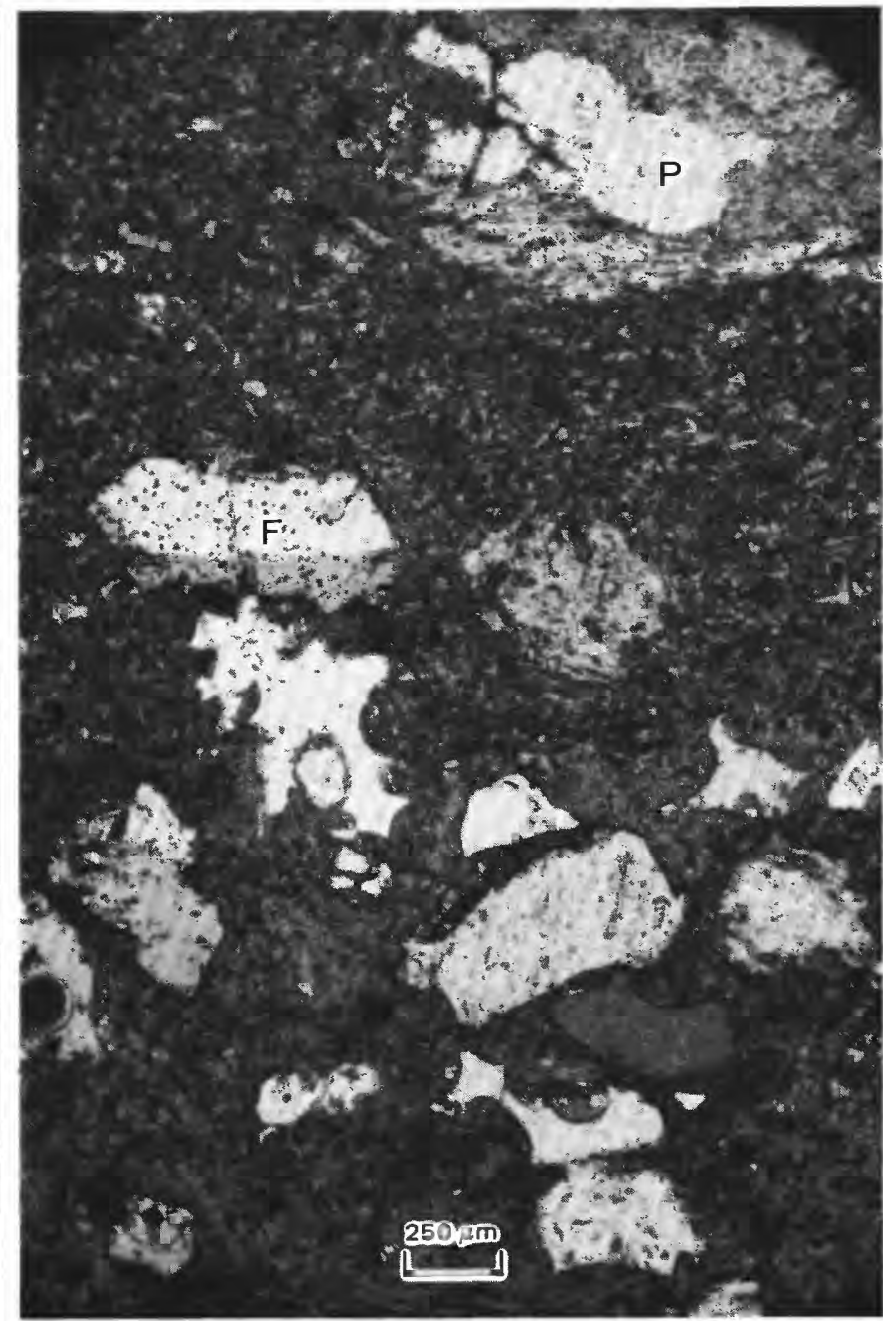

FIGURE 9.-Photomicrograph of turbidite tuff layer, Aksitero Formation, showing angular sand-size volcaniclastic grains embedded in fine-grained matrix of small glass shards replaced by mordenite. Coarse secondary calcite has replaced most of coarse volcaniclastic grains. Large pumice fragment $(P)$ at upper right has been replaced by several calcite crystals. Single calcite crystals have replaced glass shards, some showing broken edges of round-bubble vesicles (lower half). Twinned plagioclase grain (F) remained unaffected. Partly crossed nicols.

glass shards in the upper, porcelaneous parts of the turbidite beds and also occurs as a cement between the fragments to form a dense and very hard rock. In the lower, sandy parts of the turbidite layers, both mordenite and clinoptilolite (figs. $8 C$ and 10 ) replace glass shards and pumice. Clinoptilolite also forms even rims of cement crystals that line intergranular pores and vesicles within pumice fragments (fig. 10A).

Mordenite, which is much more abundant than clinoptilolite, occurs as very small needlelike length-fast fibers less than 2 micrometers in diameter and some tens of micrometers long. Clinoptilolite is present most 

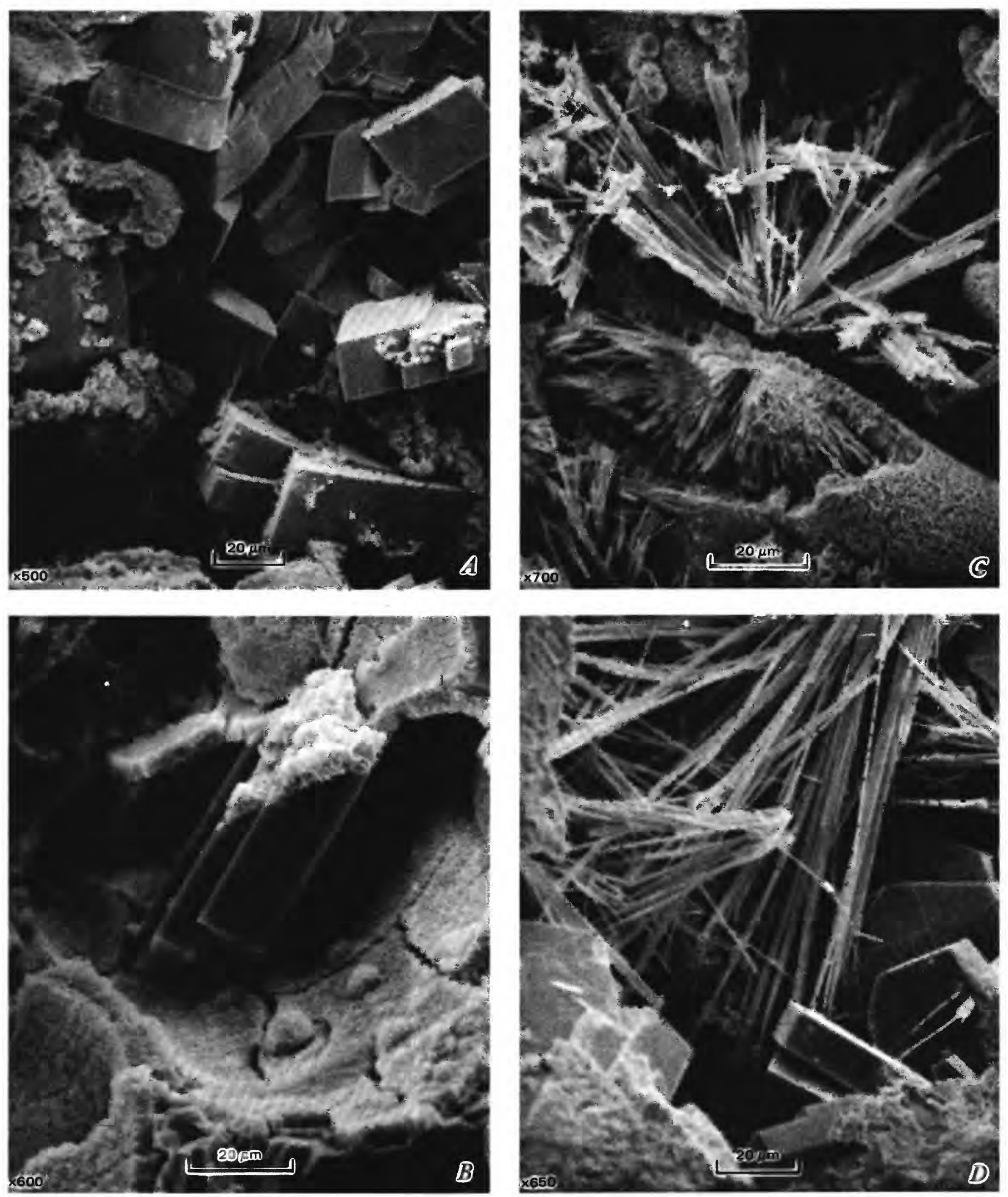

FiguRE 10.--Scanning electron micrographs of zeolites in tuffaceous turbidite, Aksitero Formation. Specimen is from basal part of graded turbidite (c in fig. 7). A, Euhedral crystals of clinoptilolite that formed as intergranular cement. $B$, Elongate clinoptilolite crystals in altered pumice fragment that in part replaced pumice and

in part grew into vesicle cavity. $C$, Rosettes of acicular mordenite crystals in pumice fragment with long-tube vesicles. Mordenite both replaced glass in pumice and filled voids. $D$, Zeolites filling vesicle in pumice fragment. Acicular mordenite at top; euhedral clinoptilolite at bottom. 
commonly as transparent, length-slow, elongated crystals up to hundreds of micrometers long, tens of micrometers wide, and having blunt crystal terminations. In replacing fragments of pumice, individual clinoptilolite crystals grew across vesicle walls so that they are in part void-filling (see Iijima, 1971, p. 334 336). Individual mordenite fibers likewise transect the edges of the glass shards that they replace.

Secondary calcite is widespread and abundant in these tuffs as intergranular cement and as replacements of glass shards and pumice fragments. In the sandy parts of the tuffs, it locally forms a cement of irregularly interlocking equigranular crystals between volcaniclastic grains (fig. $8 D$ ). Textural relations show that the calcite cement predates the zeolitic cement and presumably also the zeolitization of the shards and the pumice.

Secondary calcite is most abundant, however, as a second, post-zeolite generation of coarse-grained crystals that replaced glass shards and, to a lesser extent, crystals of plagioclase and pyroxene. Euhedral calcite rhombs, 15-50 micrometers in maximum dimension, also locally replace parts of the intergranular clinoptilolite and calcite cements. Commonly crystals of calcite up to $1 \mathrm{~mm}$ across preferentially replace shards or pumice fragments, although the surrounding finegrained tuffaceous matrix remains unaffected (figs. $8 C$ and 9). In some instances the late-generation secondary calcite forms perfect pseudomorphs after shard and pumice fragments that had been previously replaced by zeolites (fig. 9). Outlines of replaced clinoptilolite crystals are visible within the secondary calcite in places, clearly indicating that calcitization followed the zeolitization of the volcanic fragments.

Other secondary minerals include authigenic smectites, which fill some vesicles in pumiceous fragments, and length-slow chalcedony that occurs very locally as a replacement of glass shards. Scanning electron micrographs suggest the presence of small amounts of cristobalite, but cristobalite could not be detected by $\mathrm{X}$-ray diffraction.

\section{TRACES OF HYDROCARBON}

The sandy basal parts of some turbidite tuff layers have residual patches of bitumen that indicate an earlier stage when the pores were completely saturated with hydrocarbons. This bitumen does not fluoresce in ultraviolet light, but it does dissolve in carbon tetrachloride, indicating that it is "dead oil."

In thin sections, the bitumen appears as thin coatings on the surface of some grains, in cracks in feldspar grains, and on the rims of vesicles in pumice fragments (figs. $8 C$ and $8 D$ ). It also completely fills the vesicles of a few pumice fragments, forming a unique type of grain composed of bitumen-filled vesicles surrounded by zeolitized glass or by large crystals of calcite that have replaced the zeolitized glass. In one specimen, bitumen-impregnated micrite fills a foraminifer shell whose pores are also filled with bitumen. Some very porous grains, perhaps originally lithoclasts of tuffaceous mudstone, are so thoroughly impregnated with bitumen that they are black and opaque in thin section (fig. 8D).

The pores in the sandy, relatively well sorted parts of the tuffs apparently became saturated with oil early during diagenesis, because textures show that the oil predated cementation, zeolitization, and calcitization. The oil appears to have been flushed out subsequently, so that voids were reopened and later filled by calcitic and zeolitic cements. Within porous pumiceous and mudstone clasts, however, much oil remained trapped in vesicles and very small pore spaces. Consequently, layers rich in these kinds of clasts, especially pumice, tend to be dark because of residual bitumen (fig. 7).

\section{ORIGIN AND DIAGENETIC HISTORY OF THE TUFFS}

The sedimentary structures and the entrained pelagic carbonate sediment in the graded tuff layers leave little doubt that they were deposited by turbidity currents. The major question about the origin of the tuffs is whether the constituent grains formed during subaerial eruptions with subsequent reworking and redeposition by turbidity currents or during submarine ash eruptions of the kinds described by Fiske and Matsuda (1964, p. 93-96) and Fernandez (1969, p. 3536).

The composition of the tuffs suggests an entirely submarine origin because constituents are absent that would indicate source areas in shallow water or on land. With the exception of a single poorly preserved bryozoan skeleton, no benthonic shallow-water fossils were found in the tuffs. There are no wood fragments or plant remains. Indications of subaerial eruptions, such as accretionary lapilli (see Fiske, 1963, p. 402), also are absent. No significant amounts of terrigenous clastic sediment are present, and well-rounded grains, indicating multicycle sedimentary clasts or earlier abrasion in a high-energy environment, are likewise absent.

The limited composition and very angular grains in this tuff thus strongly suggest that these turbidites were fed from underwater eruption columns of pyroclastic debris. The tuffs are similar to dacitic tuffs in the Miocene Tokiwa Formation of Japan that Fiske and Matsuda (1964, p. 82-105) have shown were products of subaqueous ash flows and turbidity currents. They also somewhat resemble Quaternary lacustrine 
subaqueous pumice flow deposits in central Japan as described by Yamada (1973, p. 587-593), although some of the deposits may have been erupted on land and flowed into the water where turbidity flows were generated. The telescoping of the two turbidite layers in the bed illustrated in figure 7 resembles parts of the Tokiwa Formation where, subaqueous settling of the eruptive cloud around the vent caused repeated small surges of sediment on the sea floor. The surges in turn generated repeated turbidity currents that deposited numerous thin tuffaceous turbidites. Fiske and Matsuda (1964) noted that sequences produced by this kind of deposition are doubly graded: grain size decreases upward over some tens of meters as well as within the individual thin beds. The bed illustrated in figure 7 is also doubly graded.

Textural relations in these tuffs indicate the following sequence of postdepositional events:

1. Burial and some compaction.

2. Saturation of pore space in the sandy parts of the turbidite layers with hydrocarbons.

3. Flushing of hydrocarbons by water. Some residual oil remained attached to grains and trapped intragranular pore space.

4. In parts of the sandy layers, precipitation of intergranular calcitic cement, possibly from the pore water that flushed the hydrocarbons.

5. Zeolitization: replacement of volcanic glass in shards and in pumice fragments by mordenite and clinoptilolite, and precipitation of these minerals as void-filling cements.

6. Replacement of some zeolitized shards and pumice fragments by large crystals of secondary calcite.

Significant cementation of the tuffs must have occurred before the interbedded hemipelagic limestone became lithified. Although many foraminiferal tests are compactionally crushed in the limestone, foraminiferal shells as well as delicate pumice fragments show no signs of compaction within the tuff. One specimen consists of mordenite tuff that contains a small vertical dike filled with pelagic limestone. This relation indicates that the tuff was zeolitized, was cemented, and became brittle while the pelagic sediment remained plastic and unlithified.

\section{ZEOLITES}

The association of clinoptilolite and mordenite is common in altered tuffaceous rocks of Tertiary age (Hay, 1966, p. 65-76; Iijima and Utada, 1972, p. 7375; Seki, 1973, p. 669; Mumpton and Ormsby, 1976, p. 2,3 ). The two minerals are most abundant as replacements of silicic glass or as void-filling cements in tuffs of rhyolitic to dacitic composition. This kind of alteration may occur either in chemically active alkalisaline lakes, as in the western United States, or during burial diagenesis, as in the Aksitero Formation and in the Tertiary of Japan.

Hay's data (1966, p. 70-72) suggest that the assemblage clinoptilolite-mordenite is stable at burial depths between about 300 and $3,500 \mathrm{~m}$. On the basis of a compilation of occurrences in Japan, Iijima and Utada (1972, p. 74) and Iijima (1975, p. 135-138) found a similar range of burial depths where clinoptilolite and mordenite coexist. They surmise, however, that temperature rather than pressure is the principal controlling variable, and that the mineral pair is stable at temperatures from about $55^{\circ} \mathrm{C}$ to less than $90^{\circ} \mathrm{C}$ during the burial diagenesis of marine deposits.

The presence of clinoptilolite and mordenite in tuffs of the Aksitero Formation appears to be in general accord with the estimates of burial depths and temperatures noted above. Bandy (1963, p. 1739) and Ingle $(1975$, p. 840$)$ have reconstructed composite Tertiary sections for central Luzon that suggest the Aksitero Formation was buried beneath a maximum of 3.5-4 $\mathrm{km}$ of younger sediment (see fig. 2). At geothermal gradients of $15^{\circ}-20^{\circ} \mathrm{C} / \mathrm{km}$, values derived from a borehole measurement in northern Mindanao (Sass and Munroe, 1970 , p. 4393 ), and assuming a surface temperature of $20^{\circ} \mathrm{C}$, the maximum temperatures at those burial depths would have been in the range $70^{\circ}$ to $100^{\circ} \mathrm{C}$.

The Philippine occurrence suggests further that slight textural and compositional differences may determine the exact site where the two minerals form. Whereas mordenite and clinoptilolite are both present in the pumice-rich, basal parts of the tuffaceous turbidites, mordenite is the only zeolite in the upper, finegrained parts of the turbidites that are composed largely of very small glass shards. Seki, Oki, Odaka, and Ozawa (1972, p. 151) described an occurrence in central Japan where laumontite is the main zeolite and mordenite is confined to thin interbeds of altered fine-grained pumiceous tuff, but the zeolitization in that instance resulted from contact metamorphism. James Boles (written commun., 1976) has suggested the possibility that mordenite in these tuffs formed first by rapid alteration of the very fine grained volcanic glass, and that clinoptilolite formed later as an alteration of the coarser shards.

\section{SEDIMENTOLOGICAL AND TECTONIC SETTING}

We interpret the Aksitero Formation as a lithified basinal hemipelagic sediment composed primarily of calcareous pelagic microplankton with admixed finegrained volcanic components (fig. 11). As noted above, 


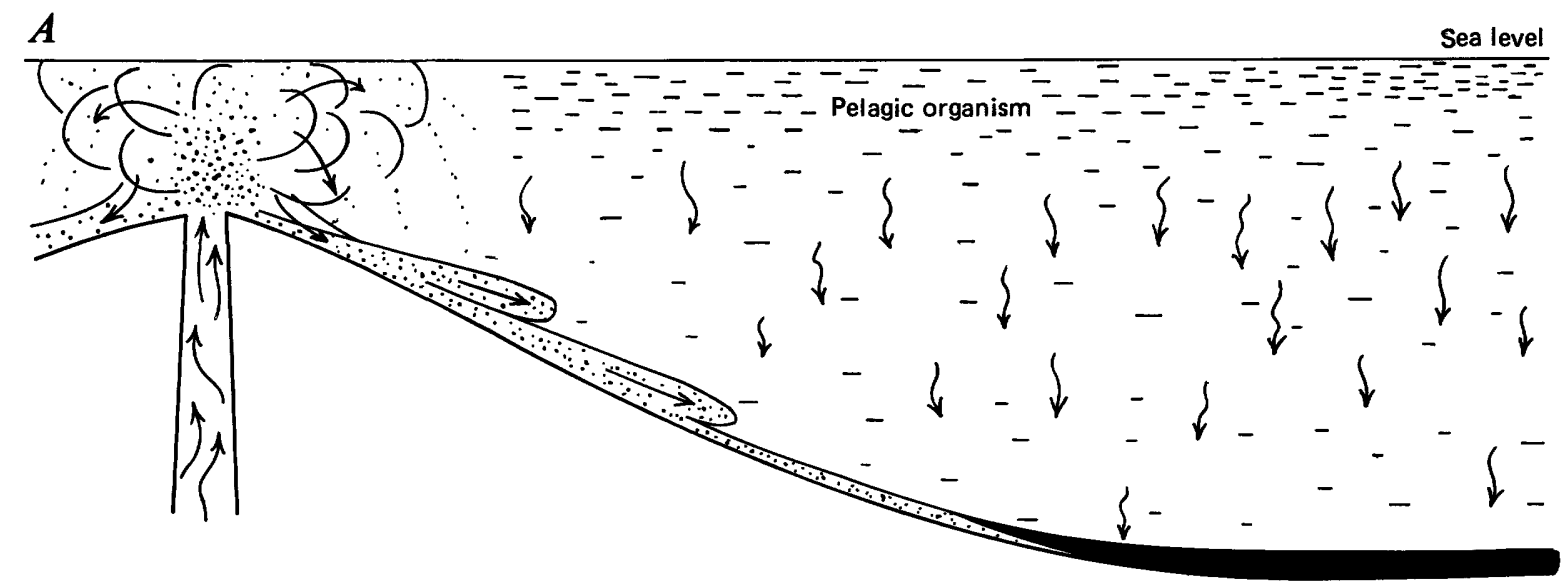

B

Sea level

Proximal volcaniclastic facies

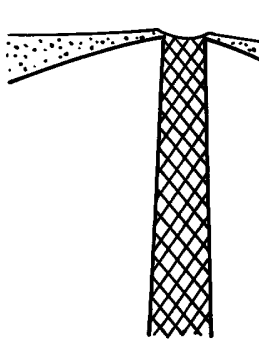

Distal volcaniclastic facies
Basinal facies (Aksitero Formation)

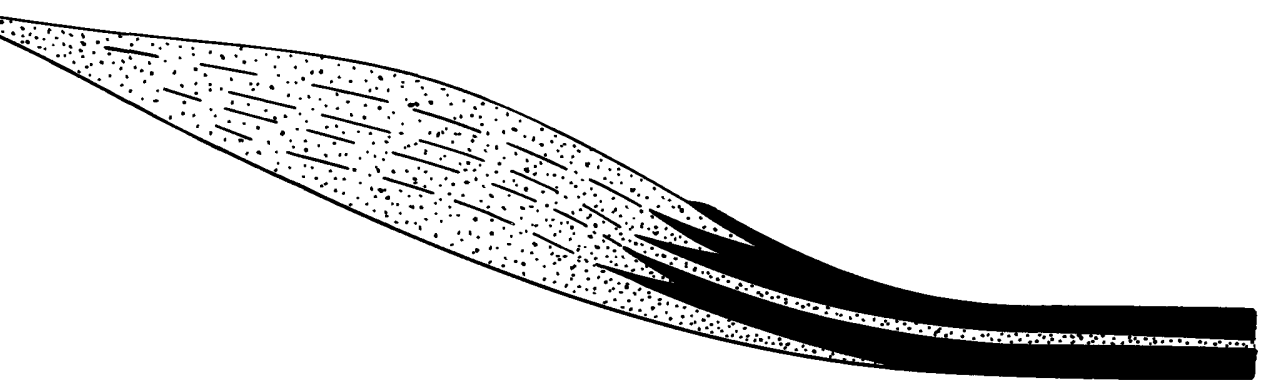

FIGURE 11.-Depositional setting of sediments in Aksitero Formation and their postulated relation to adjacent facies. A, Explosive submarine eruption at left generated subaqueous eruption cloud and gravity flows; latter includes turbidity currents that moved away from vent area (Fiske and Matsuda, 1964). Some turbidity currents reached deep basinal area at right, where predominant sediment is calcareous hemipelagic ooze. $B$, Facies developed as result of sedimentological pattern shown in $11 A$.

the basin floor probably lay at water depths of at least $1,000 \mathrm{~m}$. Turbidity currents laden with volcaniclastic sediment flowed sporadically onto the basin floor. These resulted from submarine ash eruptions and were fed from underwater eruption columns and subaqueous pyroclastic debris that had previously accumulated upslope (see Fiske and Matsuda, 1964, p. 79-105). If our interpretation is correct, the Aksitero Formation should grade laterally first into a distal volcaniclastic facies dominated by thin-bedded turbidites and then into a proximal volcaniclastic facies containing thickbedded gravity-flow deposits (fig. 11).

Eocene volcanic activity contemporaneous with dep- osition of limestone in the Aksitero Formation is widespread in the Philippines and the products of this volcanism are present as andesitic, dacitic and keratophyric flows, tuffs, and agglomerates (Philippine Bureau of Mines, 1963; Gervasio, 1973, p. 313). Most reconstructions of early Tertiary tectonic plates of the northern Philippines show Luzon on an east-facing arc, lying behind and above a west-dipping subduction zone (fig. 12; Moberly, 1972, p. 43-45; Karig, 1973, p. 164; Karig, 1975, p. 870-876; Hilde and others, 1976, p. 13). Thus the Eocene volcanism was probably associated with an island arc-trench complex of early Tertiary age that lay along the east edge of the Philippines. At 


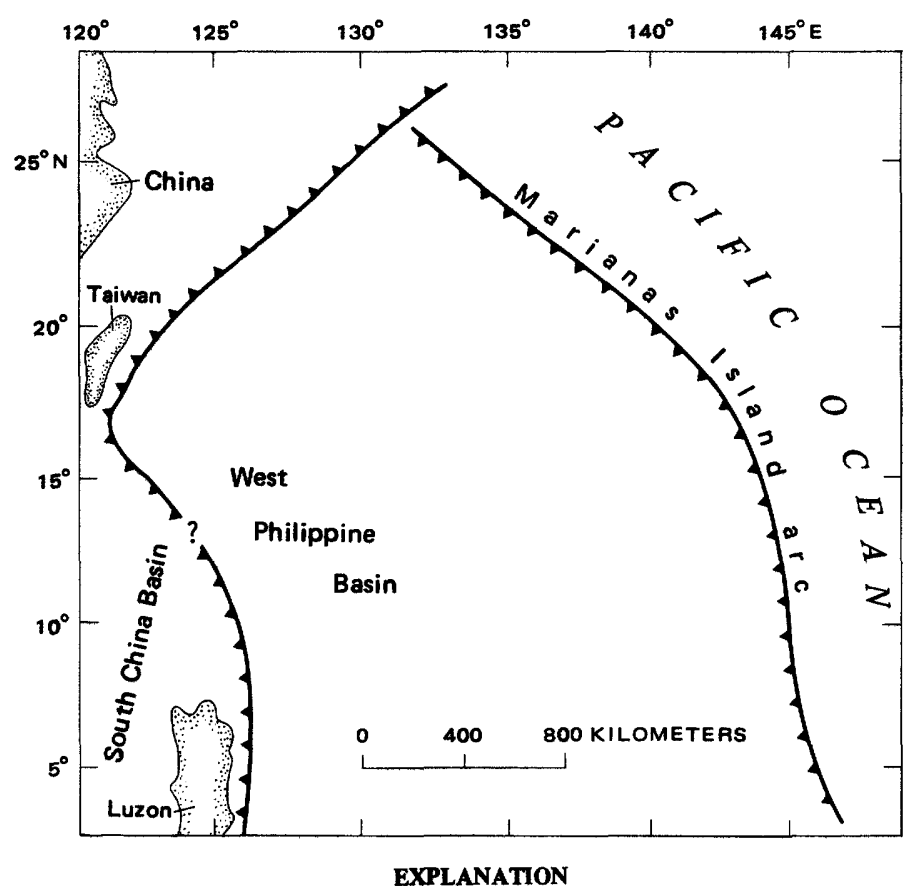

? S Subduction zone - Queried where uncertain, sawteeth point in direction of dip of subduction zone

Figure 12.-Early Tertiary plate tectonic reconstruction of the northern Philippines and Marianas region according to Karig (1973, 1975). Present-day latitude and longitude are used.

about the same time, Karig suggests that the South China Basin to the west of Luzon was apparently being opened as an extension marginal basin (Karig, 1973, p. 164). ${ }^{2}$

The Aksitero Formation, therefore, appears to have accumulated behind or to the west of an island arc-subduction complex in the eastern Philippines and on the eastern transitional edge of a major marginal basin. It directly overlies a complex ophiolitic basement sequence that has been interpreted as a remnant of an arc-trench system of Paleogene age (Ingle, 1975, p. 848). The Aksitero Formation may have been deposited on the flanks of a back-arc or interarc basin formed by extensional rifting. Karig and Glassley (1970, p. 2143-2146) have described an apparently similar setting of Pliocene age just west of the present Mariana Island arc. Dredging on the volcaniclastic aprons of this region recovered vesicular dacitic lava and foraminiferal sandstone containing dacitic glass. Karig and Glassley correlate submarine eruption of the dacitic lava with Pliocene extensional rifting of the Mariana

\footnotetext{
${ }^{2}$ Karig also believes that the West Philippine Basin, to the east of Luzon, opened as an extensional basin behind the Mariana Island arc system during middle Eocene to early Oligocene time (fig. 12; Karig, 1975, p. 876-878). This episode of extensional tectonics, which was contemporaneous with deposition of the Aksitero Formation, was accompanied by large-scale volcanism in the Marianas.
}

Island arc system. Redeposition of volcaniclastic sediment created extensive sediment aprons composed of turbidites. These volcanic aprons grade into calcareous pelagic sediment farther to the west (Karig and Moore, 1975, p. 236; Mitchell, 1970, p. 236-237) resembling the facies changes we envisage for the Aksitero Formation (fig. 11).

Ingle's paleobathymetric curve for the Tertiary of Luzon, reproduced in figure 2 of this report, suggests further that deposition of the Aksitero Formation occurred during a period of subsidence (Ingle, 1975, p. 840). This subsidence was perhaps a consequence of interarc rifting and lateral plate motion away from a spreading center within a back-arc region. In the Mariana Island arc system, Karig (1971, p. 342) has shown that substantial vertical subsidence accompanied large-scale horizontal movements in basins behind island arcs.

\section{SIGNIFICANCE OF HYDROCARBON TRACES IN THE TUFFACEOUS SEDIMENTS}

Several workers have postulated that scarcity of suitable reservoir rocks may have limited the accumulation of commercial deposits of hydrocarbons in the Philippines (Merrill, 1965, pl. 65; Mainguy, 1970, p. 103). In part, the reasoning behind this assertion is that silicic to intermediate plutonic rocks, which would yield porous quartz-rich sandstones, are relatively rare in this region.

Volcaniclastic deposits such as the turbidites in the Aksitero Formation, however, may contain considerable initial porosity in intergranular voids as well as in intragranular voids such as vesicles. These kinds of deposits, especially those containing appreciable amounts of volcanic glass, tend to be especially susceptible to diagenetic processes that occlude pore space. Among those processes is the growth of authigenic minerals. However, if the hydrocarbons migrate into the pore space before the onset of burial diagenesis (as was the case in the Aksitero tuffs) and are not subsequently flushed, then the hydrocarbons would probably serve to inhibit pore-filling diagenetic reactions (Füchtbauer, 1961).

From the above considerations, we conclude that tuffaceous sandstone like that in the Aksitero Formation is a potential oil and gas reservoir. Similar volcaniclastic rocks of Neogene age contain important hydrocarbon reserves in Japan (Ikebe and others, 1967, p. 231; Katahira and Ukai, 1976). The turbidite tuffs in the Aksitero River section are of course too thin and too few to have much reservoir capacity. However, in parts of the depositional system nearer the source vents, thicker tuffaceous sand units may occur (fig. 11). 
For example, in the Miocene subaqueous tuffs described by Fiske and Matsuda in Japan (1964, p. 82100 ), tuffaceous sands are present in sequences that are hundreds of meters thick, and one single bed is more than $50 \mathrm{~m}$ thick (see also Yamada, 1973, p. 592594). This kind of proximal volcaniclastic facies could contain hydrocarbons where it interfingers with organic-rich rocks of the basinal facies, such as the limestones of the Aksitero Formation. Amato's work (1965, p. 6,7$)$ suggests that such proximal facies might occur southeast of the Aksitero River section, where he detected a transition across a basin margin.

\section{REFERENCES CITED}

Alietti, Andrea, 1972, Polymorphism and crystal-chemistry of heulandites and clinoptilolites: Am. Mineralogist, v. 57, p. 14481462.

Amato, F. L., 1965, Stratigraphic paleontology in the Philippines: Philippine Geologist, v. 19 , no. 1, p. 1-24.

Bandy, O. L., 1962, Cenozoic planktonic foraminiferal zonation and basinal development for the Philippines: Philippine Geologist, v. 16 , p. $12-34$.

1963, Cenozoic planktonic foraminiferal zonation and basinal development in Philippines: Am. Assoc. Petroleum Geologists Bull., v. 47, p. 1733-1745.

Bouma, A. H., 1962, Sedimentology of some flysch deposits: Amsterdam, Elsevier, 168 p.

Bukry, David, 1973, Coccolith stratigraphy, Eastern Equatorial Pacific, Leg 16, Deep Sea Drilling Project, in Van Andel, T. H., Heath, G. R., and others, 1973, Initial reports of the Deep Sea Drilling Project, Volume 16: Washington, U.S. Govt. Printing Office, p. 653-700.

Corby, G. W., and others, 1951, Geology and oil possibilities of the Philippines: Rep. Philippines, Dept. Agriculture and Natural Resources, Tech. Bull. no, 21, 363 p.

Divino-Santiago, Paz, 1963, Planktonic foraminiferal species from west side Tarlac Province, Luzon Central Valley: Philippine Geologist, v. 17, no. 3, p. 69-99.

Fernandez, H. E., 1969, Notes on the submarine ash flow tuff in Siargo Island, Suriagao del Norte: Philippine Geologist, v. 23, p. 29-36.

Fischer, A. G., Honjo, S., and Garrison, Robert E., 1967, Electron micrographs of limestones and their nannofossils: Princeton, N.J., Princeton Univ. Press, 141 p.

Fiske, R. S., 1963, Subaqueous pyroclastic flows in the Ohanapecosh Formation, Washington: Geol. Soc. America Bull., v. 74, p. 391406.

1969, Recognition and significance of pumice in marine pyroclastic rocks: Geol. Soc. America Bull., v. 80, p. 1-8.

Fiske, R. S., and Matsuda, Tokihiko, 1964, Submarine equivalents of ash flows in the Tokiwa Formation, Japan: Am. Jour. Sci., v. 262 , p. $76-106$.

Füchtbauer, Hans, 1961, Zur Quarzneubildung in Erdöllagerstätten: Erdöl u. Kohle, Bd. 14, p. 169-173.

Garrison, R. E., 1975, Neogene diatomaceous sedimentation in East Asia: A review with recommendations for further study: United Nations, Economic Commission for Asia and the Far East, Committee for Coordination of Joint Prospecting for Mineral Resources in Asian Offshore Areas (CCOP), Tech. Bull., v. 9, p. 5769 .

Gervasio, F. C., 1973, Geotectonic development of the Philippines, in Coleman, P. J., ed., The Western Pacific-Island arcs, marginal seas, geochemistry: Nedlands, Univ. of Western Australia Press, p. 307-324.

Grey, R. R., 1967, Time-stratigraphic correlation of Tertiary rocks in the Philippines: Philippine Geologist, v. 21, p. 1-20.

Hay, R. L., 1966, Zeolites and zeolitic reactions in sedimentary rocks: Geol. Soc. America Spec. Paper 85, 129 p.

Hilde, T. W. C., Uyeda, S., and Kroenke, L., 1976, Evolution of the Western Pacific and its margin: United Nations, Economic Commission for Asia and the Far East, Committee for Coordination of Joint Prospecting for Mineral Resources in Asian Offshore Areas (CCOP), Tech. Bull., v. 10, p. 1-19.

Iijima, Azuma, 1971, Composition and origin of clinoptilolite in the Nakanosawa Tuff of Rumoi, Hokkaido: Advances in Chemistry Series, Washington, Am. Chem. Soc., No. 101, "Molecular Sieve Zeolites-I," p. 334-341.

-1975 , Effect of pore water to clinoptilolite-analcime-albite reaction series: Jour. Faculty Science, Univ. of Tokyo, Sec. II, v. 19 , no. 2 , p. $133-147$.

Iijima, Azuma, and Utada, M., 1972, A critical review on the occurrence of zeolites in sedimentary rocks in Japan: Japanese Jour. Geol. and Geography, v. 42, p. 61-84.

Ikebe, Y., Ishiwada, Y., and Kawai, K., 1967, Petroleum geology of Japan: United Nations, Economic Commission for Asia and the Far East, Mineral Resources Devel. Ser., v. 26, no. 1, p. 225234.

Ingle, J. C., Jr., 1975, Summary of late Paleogene-Neogene insular stratigraphy, paleobathymetry, and correlations, Philippine Sea and Sea of Japan region, in Karig, D. E., Ingle, J. C., Jr., and others, Initial reports of the Deep Sea Drilling Project: Washington, U.S. Govt. Printing Office, v. 31, p. 837-855.

Karig, D. E., 1971, Structural history of the Mariana island arc system: Geol. Soc. America Bull., v. 82, p. 323-344.

1973, Plate convergence between the Philippines and the Ryukyu Islands: Marine Geology, v. 14, p. 153-168.

1975, Basin genesis in the Philippine Sea, in Karig, D. E., Ingle, J. C., Jr., and others, Initial reports of the Deep Sea Drilling Project, Volume 31: Washington, U.S. Govt. Printing Office, p. 857-879.

Karig, D. E., and Glassley, W. E., 1970, Dacite and related sediment from the West Mariana Ridge, Philippine Sea: Geol. Soc. America Bull., v. 81, p. 2143-2146.

Karig, D. E., and Moore, G. F., 1975, Tectonically controlled sedimentation in marginal basins: Earth and Planetary Sci. Letters, v. 26 , p. $233-238$.

Katahira, T., and Ukai, M., 1976, Petroleum fields of Japan with volcanic-rock reservoirs-summary, in Halbouty, M. T., Maher, J. C., and Lian, H. M. (eds.), Circum-Pacific Energy and Mineral Resources: Amer. Assoc. Petroleum Geologists Mem. 25, p. 276279.

Mainguy, M., 1970, Regional geology and petroleum prospects of the marine shelves of eastern Asia: United Nations, Economic Commission for Asia and the Far East, Committee for Coordination of Joint Prospecting for Mineral Resources in Asian Offshore Areas (CCOP), Tech. Bull., v. 3, p. 91-107.

Merrill, W. R., 1965, Oil exploration-Philippines: Philippine Geologist, v. 19 , no. 3 , p. $65-85$.

Middleton, G. V., 1967, Experiments on density and turbidity currents, III, deposition of sediment: Canadian Jour. Earth Sci., v. 4 , p. $475-505$.

Mitchell, A. H., 1970, Facies of an early Miocene volcanic arc, Malekula Island, New Hebrides: Sedimentology, v. 14, p. 201-243.

Moberly, Ralph, 1972, Origin and history of lithosphere behind island arcs, with reference to the western Pacific: Geol. Soc. America Mem. 132, p. 35-55. 
Mumpton, F. A., and Ormsby, W. C., 1976, Morphology of zeolites in sedimentary rocks by scanning electron microscopy: Clays and Clay Minerals, v. 24, p. 1-23.

Niem, A. R., 1977, Mississippian pyroclastic flow and ash-fall deposits in the deep-marine Ouachita flysch basin, Oklahoma and Arkansas: Geol. Soc. America Bull., v. 88, p. 49-61.

Philippine Bureau of Mines, 1963, Geological Map of the Philippines, Sheet ND-51, City of Manila: Philippine Bur. Mines, scale $1: 1,000,000$.

1976, A review of oil exploration and stratigraphy of sedimentary basins of the Philippines: United Nations, Economic Commission for Asia and the Far East, Committee for Coordination of Joint Prospecting in Asian Offshore Areas (CCOP), Tech. Bull., v. 10, p. 55-99.

Roque, V. P., Jr., Reyes, B. P., and Gonzales, B. A., 1972, Report on the comparative stratigraphy of the east and west sides of the
mid-Luzon Central Valley, Philippines: Mineral Eng. Magazine, Philippine Soc. Min., Metall. and Geol. Engineers, v. 24, p. 11-62.

Sass, J. H., and Munroe, R. J., 1970, Heat flow from deep boreholes on two island arcs: Jour. Geophys. Research, v. 75, p. 4387-4395.

Seki, Yotaro, 1973, Ionic substitution and stability of mordenite: Geol. Soc. Japan Jour., v. 29, p. 669-676.

Seki, Yotaro, Oki, Yasue, Odaka, Shigeo, and Ozawa, Kiyoshi, 1972, Stability of mordenite in zeolite facies metamorphism of the Oyama-Isehara district, East Tanzawa Mountains, central Japan: Geol. Soc. Japan Jour., v. 78, p. 145-160.

Yamada, Eizo, 1973, Subaqueous pumice flow deposits in the Onikobe Caldera, Miyagi Prefecture, Japan: Geol. Soc. Japan Jour., v. 79, p. 585-597. 